\title{
Peran Financial Distress Sebagai Variabel Mediasi antara Good Corporate Governance dan Kinerja Keuangan, Terhadap Manajemen Laba Pada Bank Umum Syariah
}

\author{
Syadzwina Ramadhana Fitriza ${ }^{1}$, Rika Lidyah ${ }^{2}$, Tariza Putri Ramayanti ${ }^{3 *}$, Titin Hartini ${ }^{4}$, \\ Mismiwati $^{5}$ \\ 1,2,3,4,5 Universitas Islam Negeri Raden Fatah Palembang, Indonesia \\ ${ }^{1}$ syadzwinarf@gmail.com, 2rikalidyah_uin@radenfatah.ac.id, 3tariza.putri_uin@radenfatah.ac.id, \\ 4titinhartini_uin@radenfatah.ac.id, 5mismiwati_uin@radenfatah.ac.id \\ *Penulis Korespondensi
}

\begin{abstract}
This study aims to determine the effect of good corporate governance and financial performance on earnings management with financial distress as an intervening variable in Islamic Commercial Banks in Indonesia. This type of research is descriptive research with quantitative approach. The results showed that good corporate governance has no effect on earnings management. Financial performance and financial distress have a negative and significant effect on earnings management. Good corporate governance has a negative effect on financial distress. Financial performance has no effect on financial distress. Then, based on the result of path analysis through the causal step method, financial distress mediates the effect of good corporate governance on earnings management, while financial distress does not mediate the effect of financial performance on earnings management.
\end{abstract}

Keywords: good corporate governance, financial performance, earnings management, financial distress

\begin{abstract}
Abstrak
Penelitian ini bertujuan untuk mengetahui pengaruh good corporate governance dan kinerja keuangan terhadap manajemen laba dengan financial distress sebagai variabel mediasi pada Bank Umum Syariah di Indonesia. Jenis penelitian ini adalah penelitian deskriptif dengan pendekatan kuantitatif. Hasil penelitian menunjukkan bahwa good corporate governance tidak berpengaruh terhadap manajemen laba. Kinerja keuangan dan financial distress berpengaruh negatif dan signifikan terhadap manajemen laba. Good corporate governance berpengaruh negatif terhadap financial distress. Kinerja keuangan tidak berpengaruh terhadap financial distress. Kemudian berdasarkan hasil analisis jalur (path analysis) melalui metode causal step, financial distress memediasi pengaruh good corporate governance terhadap manajemen laba, sedangkan financial distress tidak memediasi pengaruh kinerja keuangan terhadap manajemen laba.
\end{abstract}

Kata kunci: good corporate governance, kinerja keuangan, manajemen laba, financial distress

Cara Mengutip:

Fitriza, S. R., Lidyah, R., Ramayanti, T. P., Hartini, T., \& Mismiwati. (2021). Good Corporate Governance dan Kinerja Keuangan, Terhadap Manajemen Laba Pada Bank Umum Syariah. Esensi: Jurnal Bisnis dan Manajemen, 11(2), 143-156. https://doi.org/10.15408/ess.v11i2.21508. 


\section{PENDAHULUAN}

Laba merupakan informasi potensial yang terdapat di dalam laporan keuangan dan sangat penting bagi pihak internal maupun eksternal perusahaan. Dalam penyajian laporan keuangan, manajamen perusahaan melakukan pemilihan metode akuntansi dengan tujuan tertentu. Hal ini yang disebut dengan manajemen laba (earning management) (Vinet \& Zhedanov 2011). Menurut Company et al. (1976), tindakan manajemen laba yang dilakukan seseorang didasari oleh adanya konflik kepentingan antara shareholder dan manajer yang tidak menemukan titik temu atas utilitas maksimal diantara mereka (Company et al., 1976).

Adanya tindakan manajemen laba dapat menimbulkan skandal penyajian laporan keuangan yang mengakibatkan kekhawatiran karena bertujuan untuk mengelabui para pengguna yang menyebabkan tidak transparan laporan keuangan (Vinet \& Zhedanov 2011). Banyak kasus manipulasi keuangan yang muncul karena perusahaan melakukan earning management contoh salah satunya adalah kasus laporan keuangan yang dilakukan perusahaan perbankan. Kasus yang terkait adalah kasus modifikasi laporan keuangan yang terjadi pada PT. Bank Bukopin Tbk tahun 2015, 2016, dan 2017. Bank Bukopin merevisi turun laba bersih 2016 menjadi Rp 183,56 miliar dari sebelumnya Rp 1,08 triliun. Penurunan terbesar adalah di bagian pendapatan provisi dan komisi yang merupakan pendapatan dari kartu kredit. Pendapatan ini turun dari Rp 1,06 triliun menjadi Rp 317,88 miliar. Selain masalah kartu kredit, revisi juga terjadi pada pembiayaan Bank Syariah Bukopin (BSB) terkait penambahan saldo cadangan kerugian penurunan nilai debitur tertentu, Akibatnya, beban penyisihan kerugian penurunan nilai atas aset keuangan meningkat dari Rp 649,05 miliar menjadi Rp 797,65 miliar. Hal ini menyebabkan beban perseroan meningkat Rp 148,06 miliar (Banjarnahor 2018).

Terjadinya kasus tersebut menunjukkan bahwa masih terdapat lemahnya penerapan corporate governance yang ada. Corporate governance merupakan suatu konsep untuk meningkatkan kinerja manajemen dalam monitoring kinerja dan menjamin akuntabilitas manajemen terhadap shareholder berdasarkan pada kerangka pengaturan (Anhara 2015). Agency theory memberikan gambaran bahwa masalah manajemen laba dapat diminimalisir melalui pengawasan good corporate governance. Pengawasan tersebut dapat diwujudkan dengan adanya implementasi pada tata kelola perusahaan tersebut, dimana dapat dilihat pada Grafik 1.

Grafik 1. Penilaian GCG Bank Umum Syariah 2017

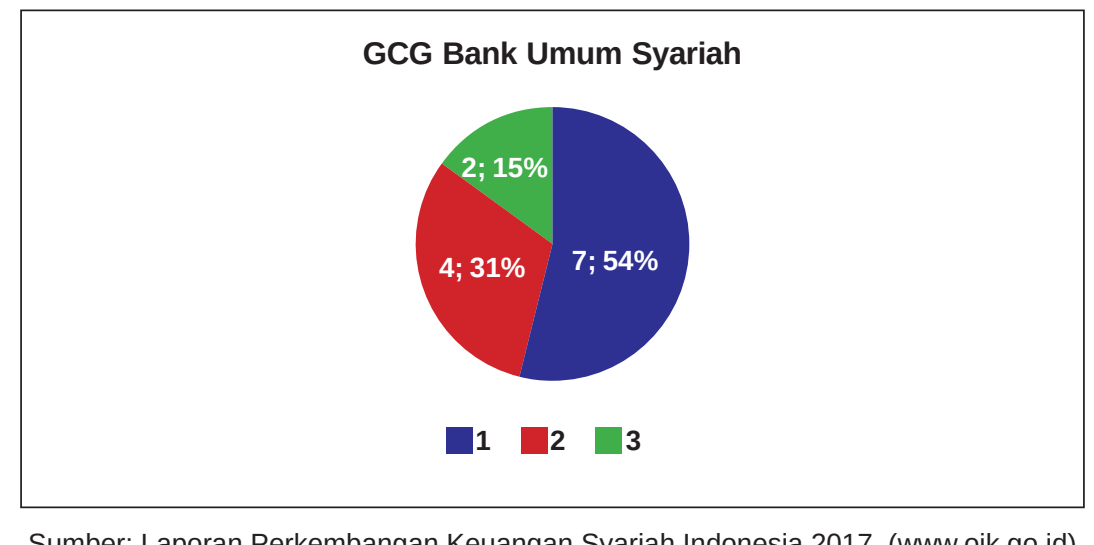


Dalam perbankan syariah untuk melihat kesehatan bank dapat dilihat pada kinerja laporan keuangan yang bertujuan untuk memperoleh laba yang maksimal. Untuk mengukur kinerja keuangan dilakukan dengan cara menganalisis rasio profitabilitas dalam mengukur kemampuan laba. Pada teori menyatakan semakin besar Return on Asset (ROA) suatu bank, semakin besar pula tingkat keuntungan yang dicapai dan semakin baik pula posisi bank tersebut dari segi penggunaan aset. ROA yang positif menunjukkan bahwa dari total aktiva yang dipergunakan untuk beroperasi, perusahaan mampu memberikan laba bagi perusahaan. Sebaliknya apabila ROA yang negatif disebabkan laba perusahaan dalam kondisi negatif pula atau rugi, hal ini menunjukkan kemampuan dari modal yang diinvestasikan secara keseluruhan belum mampu untuk menghasilkan laba. Grafik 2 merupakan data pergerakan ROA dan laba/rugi pada Bank Umum Syariah.

Grafik 2. Data Pergerakan ROA dan Laba/Rugi Bank Umum Syariah Periode 2014-2019

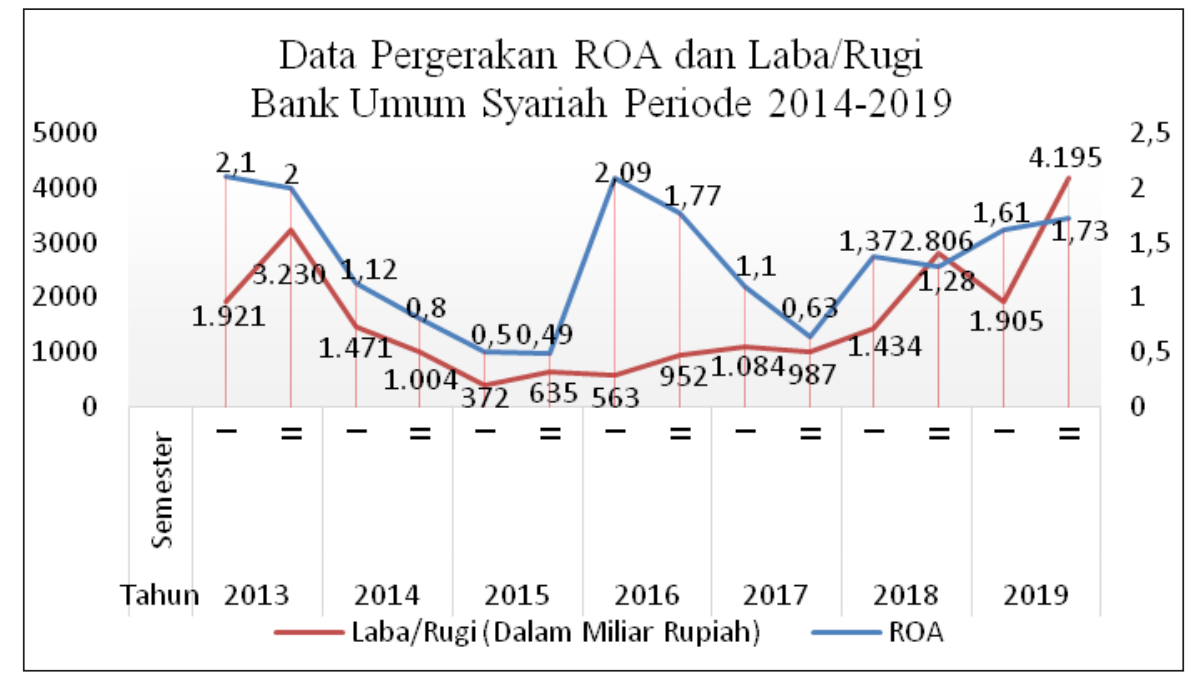

Sumber: Statistik Perbankan Syariah (2020)

Menurut Statement of Financial Accounting Concepts No. 1 dalam Belkaoui (1993), informasi laba merupakan perhatian utama untuk menaksir kinerja atau pertanggung jabawan manajemen. Adanya kecenderungan lebih memperhatikan laba dalam pihak manajemen yang digunakan untuk mengukur kinerja berdasarkan informasi tersebut dapat mendorong timbulnya perilaku menyimpang yang salah satu bentuknya yaitu manajemen laba (earnings management). Kesehatan perusahaan akan mencerminkan kemampuan dalam menjalankan usahanya, keefektifan penggunaan aset, hasil usaha yang telah dicapai, kewajiban yang harus dilunasi dan potensi kebangkrutan yang akan terjadi. Masalah keuangan yang dihadapi apabila dibiarkan dapat mengakibatkan potensi terjadinya kebangkrutan atau yang disebut dengan financial distress. Perusahaan yang sedang mengalami financial distress cenderung melakukan praktik manajemen laba sebagai usaha untuk menarik perhatian para investor (Saraswati et al., 2016; Chhapra et al., 2020).

Penelitian Suryanto (2017), Janrosl \& Lim (2019) menunjukkan good corporate governance berpengaruh positif terhadap manajemen laba. Penelitian Ewanto et al. (2011), Riadiani \& Wahyudin (2015) menunjukkan good corporate governance tidak berpengaruh 
terhadap manajemen laba. Penelitian Aprina \& Khairunisa (2015), Putri \& Machdar (2017) menunjukkan kinerja keuangan berpengaruh negatif terhadap manajemen laba. Penelitian Damayanti \& Kawedar (2019) menunjukkan kinerja keuangan tidak berpengaruh terhadap manajemen laba. Penelitian Riadiani \& Wahyudin (2015), Ghazali et al. (2015) menunjukkan financial distress berpengaruh negatif terhadap manajemen laba. Penelitian Ewanto et al. (2011) menunjukkan financial distress tidak berpengaruh terhadap manajemen laba. Penelitian Masak \& Noviyanti (2019), Gunawijaya (2015) menunjukkan good corporate governance berpengaruh negatif terhadap financial distress. Penelitian Haq \& Harto (2019) menunjukkan good corporate governance tidak berpengaruh terhadap financial distress. Penelitian Haq \& Harto (2019) menunjukkan kinerja keuangan berpengaruh negatif terhadap financial distress. Penelitian Suhadi \& Kusumaningtias (2018), Rohmadini et al. (2018) menunjukkan bahwa kinerja keuangan tidak berpengaruh terhadap financial distress.

Good corporate governance merupakan mekanisme yang digunakan untuk membatasi timbulnya masalah asimetri informasi yang dapat mendorong terjadinya manajemen laba. Komite audit sangat berperan dalam hal menjaga kredibilitas penyusunan laporan keuangan, serta pelaksanaannya terhadap good corporate governance. Perusahaan dapat menjadi lebih baik dan terhindar dari konflik keagenan jika komite audit berjalan secara efektif. Ada beberapa manfaat dari pembentukan komite audit dalam perusahaan yaitu komite audit melakukan pengawasan laporan keuangan dan pelaksanaan audit eksternal, komite audit melakukan pengawasan independen terhadap pengelolaan perusahaan, dan juga komite audit melaksanakan pengawasan independen atas proses pelaksanaan yag baik dalam memengaruhi kualitas pelaporan keuangan yang pada akhirnya akan mempengaruhi manajemen laba (Abdillah, 2014). Namun, seringkali manajemen tidak mengelola perusahaan untuk meningkatkan nilai dan kinerja melainkan hanya untuk memenuhi kepentingan pribadi. Semakin berperan komite audit dalam perusahaan maka akan semakin tinggi pula tindakan manajemen yang dilakukan (Suryanto, 2017). Pernyataan tersebut didukung oleh penelitian yang dilakukan Suryanto (2017), serta Janrosl \& Lim (2019) yang menyatakan bahwa good corporate governance berpengaruh positif dan signifikan terhadap manajemen laba.

Efektivitas perusahaan dalam menghasilkan laba melalui pengoperasian aktiva yang dimiliki menjadi tolak ukur kinerja perusahan dapat pula memotivasi tindakan manajemen laba pada suatu perusahaan (Dewi et al., 2019). Salah satu tujuan perusahaan adalah untuk memperoleh laba. Return On Assets (ROA) digunakan untuk mengukur kemampuan manajemen bank dalam memperoleh laba (profit). Political cost menyatakan bahwa perusahaan cenderung memilih dan menggunakan metode akuntansi yang dapat memperkecil atau memperbesar laba yang dilaporkannya. Manajer akan mempermainkan laba agar kewajiban pembayaran tidak terlalu tinggi sehingga alokasi laba sesuai dengan kemauan perusahaan. Apabila laba perusahaan tinggi maka manajer cenderung akan melakukan praktik manajemen laba dengan cara menurunkan laba agar pajak yang dikenakan pemerintah kepada perusahaan kecil. Pernyataan tersebut didukung oleh penelitian yang dilakukan Putri \& Machdar (2017) yang menyatakan bahwa kinerja keuangan berpengaruh negatif dan signifikan terhadap manajemen laba.

Teori keagenan (agency theory) memprediksi bahwa tingkat financial distress perusahaan dapat memotivasi manajer melakukan manajemen laba oportunistik. Jika dikaitkan dengan agency problem, hal ini terletak pada sebab bagaimana financial distress dapat terjadi. 
Ketika perusahaan dalam tahap resesi keuangan hal ini akan memungkinkan manajemen untuk melakukan insentif dari praktik manajemen laba. Jika financial distress diperkirakan bersifat sementara, kemungkinan manajer dalam melakukan manajemen laba akan lebih tinggi dan sebaliknya. Pernyataan tersebut didukung oleh penelitian yang dilakukan Riadiani \& Wahyudin (2015), serta Ghazali et al. (2015) yang menyatakan bahwa financial distress berpengaruh negatif dan signifikan terhadap manajemen laba.

Dalam teori agensi, corporate governance diperlukan untuk mengurangi agency problem agar menimbulkan keselarasan kepentingan antara pemilik perusahaan dan manajer. Dengan demikian berkurangnya konflik keagenan akan terjadi kesinambungan yang baik antara pemilik perusahaan dengan manajer dan pada akhirnya menjadikan perusahaan dalam kondisi yang kondusif sehingga tidak terjadi kondisi financial distress. Semakin besar komite audit dalam suatu perusahaan maka akan semakin kecil kemungkinan terjadinya financial distress. Pernyataan tersebut didukung oleh penelitian yang dilakukan Masak \& Noviyanti (2019), serta Gunawijaya (2015) yang menyatakan bahwa good corporate governance berpengaruh negatif dan signifikan terhadap financial distress.

Return on Asset (ROA) yaitu dimana seberapa besar laba bersih yang diperoleh perusahaan yang diukur dari nilai aktiva, semakin besar laba yang didapat semakin kecil kemungkinan terjadinya financial distress perusahaan. Menurut teori keagenan (agency theory) kegiatan operasi perusahan adalah tugas agen. Oleh karena itu, jika suatu perusahaan mempunyai nilai ROA yang tinggi maka laba yang didapat juga tinggi, dan dapat dikatakan bahwa agen berhasil mengambil keputusan terbaik dalam mengelola perusahaan. Pernyataan tersebut didukung oleh penelitian yang dilakukan Haq \& Harto (2019) yang menyatakan bahwa kinerja keuangan berpengaruh negatif dan signifikan terhadap financial distress.

Jika good corporate governance berpengaruh secara langsung terhadap financial distress, maka menandakan bahwa financial distress atas komite audit juga meningkat, dengan meningkatnya financial distress maka secara langsung dapat berpengaruh terhadap good corporate governance yang juga akan mengalami peningkatan. Pernyataan tersebut didukung oleh peneliti terdahulu yang dilakukan Masak \& Noviyanti (2019), serta Gunawijaya (2015) yang menyatakan berpengaruh terhadap financial distress. Kemudian financial distress berpengaruh terhadap manajemen laba. Pernyataan tersebut didukung oleh penelitian terdahulu yang dilakukan Riadiani \& Wahyudin (2015), serta Ghazali et al., 2015) yang menyatakan berpengaruh terhadap manajemen laba.

Jika kinerja keuangan berpengaruh secara langsung terhadap financial distress, maka menandakan bahwa financial distress atas komite audit juga meningkat, dengan meningkatnya financial distress maka secara langsung dapat berpengaruh terhadap kinerja keuangan yang juga akan mengalami peningkatan. Kinerja Keuangan dengan proksi ROA (Return on Assets) berpengaruh terhadap financial distress. Pernyataan tersebut didukung oleh peneliti terdahulu yang dilakukan (Haq and Harto 2019; Shidiq \& Wibowo, 2017) yang menyatakan berpengaruh terhadap financial distress. Selanjutnya financial distress berpengaruh terhadap manajemen laba. Pernyataan tersebut didukung oleh penelitian terdahulu yang dilakukan Riadiani \& Wahyudin (2015), dan Ghazali et al. (2015) yang menyatakan berpengaruh terhadap manajemen laba. Maka dari itu, financial distress mampu memediasi pengaruh kinerja keuangan terhadap manajemen laba. 
Penelitian ini bertujuan untuk mengetahui pengaruh good corporate governance dan kinerja keuangan terhadap manajemen laba dengan financial distress sebagai variabel mediasi pada Bank Umum Syariah di Indonesia. Hal inilah yang menjadi kontribusi utama di dalam penelitian ini. Masuknya financial distress sebagai variabel mediasi menjadi pembeda antara penelitian ini dengan penelitian terdahulu.

\section{METODE}

Jenis penelitian ini adalah penelitian deskriptif dengan pendekatan kuantitatif. Pendekatan kuantitatif digunakan untuk menjelaskan dan menguji hubungan antar variabel, menemukan kausalitas dari variabel, menguji teori, dan mencari generalisasi dari suatu prediktif. Sumber data yang digunakan merupakan data sekunder yang diperoleh dalam bentuk yang sudah jadi, sudah dikumpulkan dan diolah pihak lain dan sudah dipublikasi (Muhammad 2008). Populasi yang digunakan pada penelitian adalah 14 Bank Umum Syariah yang terdaftar di Otoritas Jasa Keuangan (OJK). Penentuan sampel menggunakan metode purposive sampling dan berdasarkan metode tersebut, terdapat lima sampel yang digunakan dalam penelitian ini. Tabel 1 menunjukkan variabel yang dipergunakan di dalam penelitian ini.

Tabel 1. Tabel Operasional Variabel

\begin{tabular}{llcc}
\hline \multicolumn{1}{c}{ Variabel } & Pengukuran & Skala \\
\hline 1. Good Corporate Governance & $\begin{array}{c}\text { Komite Audit }= \\
\text { RAnggota Komite Audit } \\
\text { 2. }\end{array}$ Kinerja Keuangan & $\begin{array}{c}\text { Raba Sebelum Pajak)/(Total } \\
\text { Aktiva }) \times 100 \%\end{array}$ & Rasio \\
& DAit $=$ TAit-1 - NDAit & Rasio \\
3. $\begin{array}{l}\text { Manajemen Laba } \\
\text { (Discretionary Accrual) }\end{array}$ & Financial Distress & $\mathrm{Z}=\mathbf{6 . 5 6 \times 1 + 3 . 2 6 \times 2 + 6 . 7 2 \times 3 + 1 . 0 5 \times 4}$ & Rasio \\
\hline
\end{tabular}

Berdasarkan judul penelitian, maka model analisis jalur dalam penelitian ini terlihat dalam Gambar 1. Menurut (Juliansyah 2011), persamaan struktural adalah persamaan yang menyamakan hubungan antar variabel pada diagram jalur yang ada. Berdasarkan diagram jalur pada gambar di atas, terdapat 2 bentuk persamaan struktural, yaitu:

Persamaan struktural 1:

$M=\alpha+\beta$ Good Corporate Governance $+\beta$ Kinerja Keuangan $+\mathrm{e} 1$

Persamaan struktural 2:

$\mathrm{Y}=\alpha+\beta$ Good Corporate Governance $+\beta$ Kinerja Keuangan $+\beta$ Financial Distress $+\mathrm{e} 1$

Gambar 1. Analisa Jalur

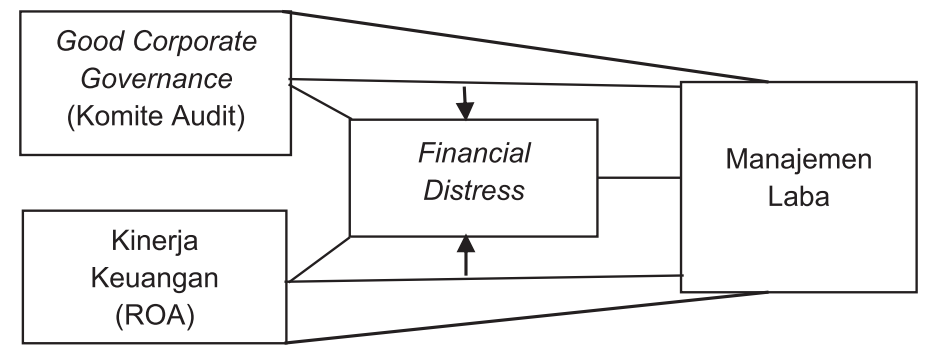




\section{HASIL DAN PEMBAHASAN}

\section{Hasil Uji Asumsi Klasik}

Berdasarkan tabel 2 menunjukkan bahwa data uji normalitas berdistribusi normal yaitu Asymp.Sig struktur 1 sebesar 0,261>0,05 dan struktur 2 sebesar 0,573>0,05. Pada uji multikolinieritas menunjukkan bahwa data tidak mengandung gejala multikolinier yaitu nilai TOL pada struktur 1 dan struktur $2>0,1$ dan nilai VIF pada struktur 1 dan struktur $2<10$. Pada uji heterokedastisitas menunjukkan bahwa data tidak terjadi gejala heterokedastisitas, yaitu struktur 1 nilai chi square hitung 6,230 < chi square tabel 11,071 dan struktur 2 chi square hitung 11,375 < chi square tabel 14,067. Pada uji autokorelasi menunjukkan bahwa data tidak ada autokorelasi, yaitu nilai Durbin-Watson pada struktur 1 sebesar 1,048 dan struktur 2 sebesar 0,576. Pada uji linearitas menunjukkan bahwa data terjadi hubungan linier, yaitu struktur 1 nilai chi square hitung 0,035 < chi square tabel 49,802 dan struktur 2 chi square hitung $1,050<$ chi square tabel 49,802 .

Tabel 2. Hasil Uji Asumsi Klasik

\begin{tabular}{|c|c|c|c|c|c|c|}
\hline \multicolumn{7}{|c|}{ Uji Asumsi Klasik } \\
\hline \multirow{2}{*}{$\begin{array}{l}\text { Uji Normalitas } \\
\text { (Kolmogorov-Smirnov) }\end{array}$} & \multirow{2}{*}{$\begin{array}{l}\text { Struktur } 1 \\
\text { Struktur } 2\end{array}$} & \multicolumn{3}{|c|}{ Asymp. Sig } & \multicolumn{2}{|l|}{0,261} \\
\hline & & & Asymp. Sig & & 0,573 & \\
\hline \multirow{5}{*}{$\begin{array}{l}\text { Uji Multikolinieritas } \\
\text { (Tolerance dan VIF) }\end{array}$} & Struktur 1 & $\mathrm{X} 1$ & Tolerance & 0,998 & VIF & 1,002 \\
\hline & & $\mathrm{x} 2$ & Tolerance & 0,998 & VIF & 1,002 \\
\hline & Struktur 2 & $\mathrm{X} 1$ & Tolerance & 0,841 & VIF & 1,189 \\
\hline & & $\mathrm{x} 2$ & Tolerance & 0,915 & VIF & 1,093 \\
\hline & & M & Tolerance & 0,788 & VIF & 1,269 \\
\hline \multirow{2}{*}{$\begin{array}{l}\text { Uji Heterokedastisitas } \\
\text { (White) }\end{array}$} & Struktur 1 & \multicolumn{2}{|c|}{ Chi square hitung } & 6,230 & Chi square tabel & 11,071 \\
\hline & Struktur 2 & \multicolumn{2}{|c|}{ Chi square hitung } & 11,375 & Chi square tabel & 14,067 \\
\hline \multirow{2}{*}{$\begin{array}{l}\text { Uji Autokorelasi (Durbin } \\
\text { Watson) }\end{array}$} & Struktur 1 & \multicolumn{3}{|c|}{ Durbin-Watson } & \multicolumn{2}{|l|}{1,048} \\
\hline & Struktur 2 & \multicolumn{3}{|c|}{ Durbin-Watson } & \multicolumn{2}{|l|}{0,576} \\
\hline \multirow[t]{2}{*}{ Uji Linearitas (L-M Test) } & Struktur 1 & Chi & are hitung & 0,035 & Chi square tabel & 49,802 \\
\hline & Struktur 2 & Chi & are hitung & 1,050 & Chi square tabel & 49,802 \\
\hline
\end{tabular}

Sumber: data diolah (2020)

\section{Analisis Substruktur}

Untuk struktur 1, memiliki R Square sebesar 0,163 hasil ini menunjukkan 16,3\% variabel dependen dipengaruhi oleh good corporate governance dan kinerja keuangan sedangkan sisanya sebesar $83,7 \%$ dipengaruhi oleh variabel lain yang belum diteliti. Untuk hasil struktur 2, memiliki R Square sebesar 0,515 hasil ini menunjukkan 51,5\% variabel dependen dipengaruhi oleh good corporate governance, kinerja keuangan, dan financial distress sedangkan sisanya sebesar $48,5 \%$ dipengaruhi oleh variabel lain diluar penelitian. 
Tabel 3. Hasil Uji Koefisien Determinasi

\begin{tabular}{cccc}
\hline \multicolumn{3}{c}{ Uji Koefisien Determinasi } \\
\hline Koefisien Determinasi & Model struktur 1 & R Square & $0,163->16,3 \%$ \\
& Model struktur 2 & R Square & $0,515->51,5 \%$ \\
\hline
\end{tabular}

Sumber: data diolah (2020)

Berdasarkan hasil uji simultan pada tabel 3, substruktur I diperoleh angka F hitung 4,301 dan nilai Sig. 0,022 serta substruktur II diperoleh angka F hitung 13,017 dan nilai Sig. 0,000 maka secara simultan variabel independen berpengaruh terhadap variabel dependen.

Tabel 4. Hasil Uji Simultan

\begin{tabular}{cccccc}
\hline \multicolumn{5}{c}{ Uji Simultan (Uji F) } \\
\hline Uji F (Simultan) & Substruktur I & F & 4,301 & Sig. & 0,022 \\
& Substruktur II & F & 13,017 & Sig. & 0,000 \\
\hline
\end{tabular}

Sumber: data diolah (2020)

Pada substruktur I diperoleh angka t hitung -2,449 dan nilai Sig. 0,020 maka H4 diterima. Angka t hitung 1,708 dan nilai Sig. 0,097 maka H5 ditolak. Sedangkan substruktur II diperoleh angka 1,831 dan nilai Sig. 0,077 maka H1 ditolak. Angka t hitung -2,702 dan nilai Sig. 0,011 maka H2 diterima. Angka t hitung -3,537 dan nilai Sig. 0,001 maka H3 diterima.

Tabel 5. Hasil Uji Parsial

\begin{tabular}{ccccccc}
\hline & \multicolumn{1}{c}{ Uji Parsial (Uji t) } & & & & \\
\hline $\begin{array}{c}\text { Uji t } \\
\text { (Parsial) }\end{array}$ & Substruktur I & Good Corporate Governance & t & $-2,449$ & Sig. & 0,020 \\
& & Kinerja Keuangan & t & 1,708 & Sig. & 0,097 \\
\cline { 2 - 7 } & Substruktur II & Good Corporate Governance & t & 1,831 & Sig. & 0,077 \\
& Kinerja Keuangan & t & $-2,702$ & Sig. & 0,011 \\
& Financial Distress & t & $-3,537$ & Sig. & 0,001 \\
\hline
\end{tabular}

Sumber: data diolah (2020)

Pengujian hipotesis 1: Pengaruh good corporate governance terhadap manajemen laba: berdasarkan hasil pengujian good corporate governance tidak berpengaruh terhadap manajemen laba diperoleh $t$ hitung $>\mathrm{t}$ tabel $(1,831>1,696)$ dengan nilai sig. sebesar 0,077 $>0,05$, artinya perubahan yang terjadi pada good corporate governance tidak berpengaruh terhadap manajemen laba. Hal ini dikarenakan pembentukan komite audit hanya sebatas pemenuhan regulasi dan belum dianggap berdasarkan kebutuhan perusahaan yang menyebabkan komite audit masih belum bisa menunjukkan posisi kedudukan yang berdiri sendiri dan masih bergantung pada dewan komisaris sehingga keberadaan komite audit belum cukup untuk meminimalisir tindakan manajemen laba. Keberadaan komite audit dalam perusahaan yang tidak menjalankan tugasnya dengan baik terutama pada hal memonitoring atas pelaporan keuangan. Hal inilah yang menjadi penyebab suatu kegagalan komite audit dalam mendeteksi 
secara dini kemungkinan terjadinya suatu tindakan manajemen laba di dalam perusahaan (Sulistyoningsih \& Asyik 2019). Dewan komisaris membentuk komite audit dengan maksud mengurangi sifat opportunistic manajemen, namun komite audit berada pada garis komando dewan komisaris. Anggota komite audit semacam ini sulit diharapkan untuk dapat bekerja secara profesional sehingga besar kecilnya jumlah komite audit di dalam perusahaan tidak mempengaruhi praktik manajemen laba perusahaan. Hal ini diperkuat dengan hasil penelitian yang dilakukan oleh Ewanto et al. (2011), serta Riadiani \& Wahyudin (2015) yang menyatakan bahwa good corporate governance tidak berpengaruh terhadap manajemen laba.

Pengujian hipotesis 2: pengaruh kinerja keuangan terhadap manajemen laba: Berdasarkan hasil pengujian kinerja keuangan berpengaruh negatif dan signifikan terhadap manajemen laba diperoleh $-\mathrm{t}$ hitung $<-\mathrm{t}$ tabel $(-2,702<-1,696)$ dengan nilai sig. sebesar 0,011<0,05, artinya kenaikan kinerja keuangan akan diikuti oleh penurunan manajemen laba. Salah satu tujuan perusahaan adalah untuk memperolah laba (profit), maka jika semakin kecil nilai ROA perusahaan maka akan semakin terindikasi perusahaan melakukan praktik perataan laba. Variabel tersebut berpengaruh pada perataan laba karena investor tidak dapat mengabaikan informasi profitabilitas yang ada, sehingga manajemen pun menjadi termotivasi melakukan perataan laba. Perataan laba ini merupakan salah satu dari bentuk manajemen laba. Manajer akan melakukan apa saja agar perusahaan yang dikelola mendapatkan laba sekaligus untuk menarik minat investor. Maka dari itu, saat laba perusahaan tinggi, pihak manajemen akan melakukan manajemen laba dengan cara menurunkan labanya. Ketika profitabilitas rendah manajemen juga khawatir akan adanya pergantian manajemen sehingga praktik peratan laba pun dilakukan untuk memperlihatkan bahwa laba yang diperoleh besar dan kinerja manajemen akan dinilai bagus. Hal ini diperkuat dengan hasil penelitian yang dilakukan oleh Putri \& Machdar (2017) yang menyatakan bahwa ROA berpengaruh negatif dan signifikan terhadap manajemen laba.

Pengujian hipotesis 3: pengaruh financial distress terhadap manajemen laba: berdasarkan hasil pengujian financial distress berpengaruh negatif dan signfikan terhadap manajemen laba diperoleh $-t$ hitung $<-t$ tabel $(-3,537<-1,696)$ dengan nilai sig. sebesar 0,001 $<0,05$, artinya kenaikan financial distress kan diikuti oleh penurunan manajemen laba. Hal ini dikarenakan berdasarkan teori keagenan memprediksi bahwa financial distress dapat memotivasi manajer melakukan manajemen laba opportunsitik. Sebahattin et al. (2009) mengemukakan bahwa para manajer perusahaan akan mempraktikkan manajemen laba ketika perusahaan tersebut menjalankannya tidak dalam kondisi tertekan dan akan melakukan sebaliknya jika perusahaan dalam kesulitan. Sebahattin et al. (2009) juga menjelaskan bahwa alasan utama mengapa perusahaan yang tertekan melakukannya tidak terlibat dalam manajemen laba hanya karena mereka telah menghabiskan cara memanipulasi dan mengelola laba sebelum kesulitan dan mungkin gagal untuk merasakan manfaat dari manipulasi laba tersebut Ghazali et al. (2015). Hal ini diperkuat dengan hasil penelitian yang dilakukan oleh Riadiani \& Wahyudin (2015) dan Ghazali et al. (2015) yang menyatakan bahwa financial distress berpengaruh negatif dan signifikan terhadap manajemen laba.

Pengujian hipotesis 4: pengaruh good corporate governance terhadap financial distress: berdasarkan hasil pengujian good corporate governance berpengaruh negative dan signifikan terhadap financial distress diperoleh $-\mathrm{t}$ hitung $<-t$ tabel $(-2,449<-1,694)$ dan nilai sig. 
sebesar 0,020 $<0,05$, artinya kenaikan good corporate governance akan diikuti oleh penurunan financial distress. Hal ini dikarenakan komite audit diasumsikan mampu mengurangi masalah keagenan yang timbul pada suatu perusahaan yang apabila terjadi terus-menerus dapat menimbulkan financial distress. Dalam teori keagenan disebutkan bahwa kualitas pengawasan yang dilakukan dengan baik mampu menurunkan perilaku oportunistik yang biasa dilakukan oleh manajer sebagai agen. Peraturan Bapepam-LK/No.IX.1.5 menyatakan bahwa perusahaan publik diwajibkan untuk memiliki komite audit. Adanya komite audit dengan jumlah yang tepat dapat memungkinkan anggotanya untuk menerapkan keahlian dan pengalamannya untuk kepentingan yang terbaik bagi pemegang saham (Masak \& Noviyanti, 2019). Komite audit dalam perusahaan berperan melakukan pengendalian internal dan merupakan salah satu elemen kunci dalam struktur corporate governance yang membantu mengendalikan dan mengawasi manajemen. Semakin banyak jumlah komite audit dalam suatu perusahaan dan dapat meningkatkan kinerja perusahaan menjadi lebih baik maka akan semakin kecil kemungkinan terjadinya financial distress (Haziroh \& Negoro, 2017). Hal ini diperkuat dengan penelitian yang dilakukan oleh Masak \& Noviyanti (2019) dan Gunawijaya (2015) yang menyatakan bahwa good corporate governance berpengaruh negatif dan signifikan terhadap financial distress.

Pengujian hipotesis 5: pengaruh kinerja keuangan terhadap financial distress: berdasarkan hasil pengujian kinerja keuangan tidak berpengaruh terhadap financial distress diperoleh $\mathrm{t}$ hitung $>\mathrm{t}$ tabel $(1,708>1,694)$ dan nilai sig. sebesar 0,097 $>0,05$, artinya perubahan yang terjadi pada kinerja keuangan tidak berpengaruh terhadap financial distress. Hal ini dikarenakan besarnya nilai ROA yang mengartikan bahwa laba yang diperoleh juga besar pada BUS tidak selalu perbankan dapat terhindar dari terjadinya financial distress. Dengan adanya moral hazard, dapat menjadikan utang dan penyaluran pembiayaan berlebih sehingga dapat meningkatkan risiko terjadinya financial distress, dan juga pada total aset bank yang digunakan dalam perhitungan ROA dianggap lebih likuid, karena hampir 90\% pada aset bank syariah terdiri dari pembiayaan (kredit) yang mengandung risiko. Oleh sebab itu, tinggi rendahnya nilai ROA pada perusahaan tidak selalu mempengaruhi financial distress perusahaan tersebut. Hal ini diperkuat dengan hasil penelitian yang dilakukan oleh Suhadi \& Kusumaningtias (2018) serta Rohmadini et al. (2018) yang menyatakan bahwa ROA tidak berpengaruh terhadap financial distress.

\section{Pengujian Varibel Mediasi}

Hasil analisis ditemukan bahwa financial distress signifikan terhadap manajemen laba, setelah mengontrol good corporate governance dengan nilai Sig. 0,0002 <0,05 dan koefisien regresi $(b)=-0,0317$. Selanjutnya ditemukan direct effect c' sebesar 0,0769 yang lebih kecil dari $\mathrm{c}=0,1668$. Pengaruh good corporate governance terhadap manajemen laba berkurang dan tidak signifikan 0,1960 > 0,05 setelah mengontrol variabel mediasi financial distress. Dapat disimpulkan bahwa model regresi termasuk ke dalam "full mediation" atau terjadi mediasi. 


\section{Gambar 3. Causal Step (Pengaruh Good Corporate Governance terhadap Manajemen Laba dengan dimediasi Financial Distress)}

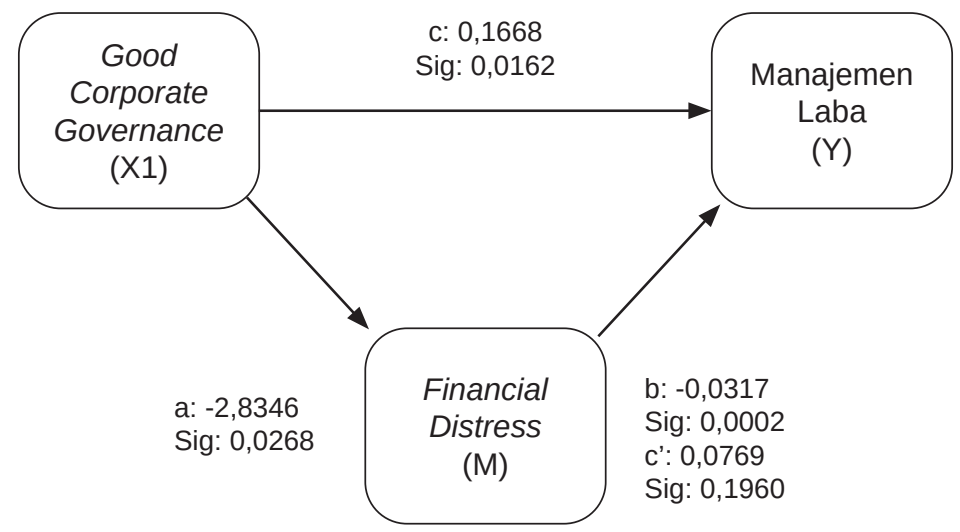

Sumber: Hasil olah data

Hasil analisis ditemukan bahwa financial distress signifikan terhadap manajemen laba, setelah mengontrol kinerja keuangan nilai Sig. 0,0001 < 0,05 dan koefisien regresi (b) = -0,0313. Selanjutnya ditemukan direct effect c' sebesar 0,0240 yang lebih besar dari $c=-0,1215$. Pengaruh kinerja keuangan terhadap manajemen laba berkurang dan signifikan 0,0240<0,05 setelah mengontrol variabel mediasi financial distress. Dapat disimpulkan bahwa model regresi termasuk ke dalam "ummediated" atau tidak terjadi mediasi.

\section{Gambar 4. Causal Step (Pengaruh Kinerja Keuangan terhadap Manajemen Laba dengan dimediasi Financial Distress)}

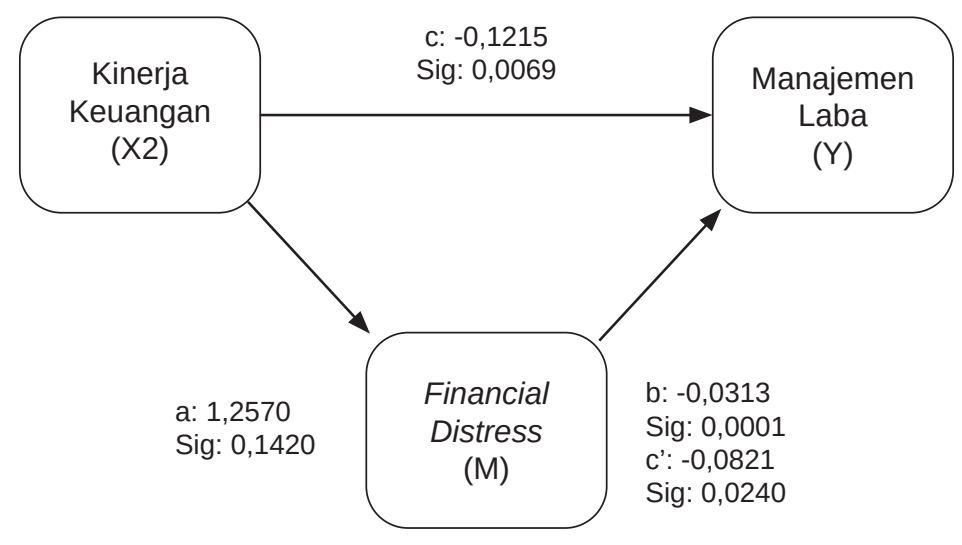

Sumber: Hasil olah data

Berdasarkan hasil pengujian menggunakan strategi causal step diperoleh hasil bahwa good corporate governance tidak mampu mempengaruhi secara signifikan variabel manajemen laba tanpa melalui variabel mediasi financial distress. Hal ini dikarenakan financial distress menjadi faktor penentu apabila perusahaan mengalami permasalahan keuangan, jika nilai financial distress terlalu rendah tentunya akan berdampak terhadap tingginya manajemen laba, komite audit tentunya akan semakin memperketat pengawasan dan pengontrolan pelaporan keuangan oleh para manajer. Komite audit yang terdapat pada perusahaan merupakan salah satu mekanisme corporate governance yang mampu mengurangi tindak manipulasi laba oleh 
manajemen. Hal ini diperkuat dengan penelitian Masak \& Noviyanti (2019) dan Gunawijaya (2015) yang menunjukkan bahwa good corporate governance berpengaruh terhadap financial distress. Serta hasil penelitian Riadiani \& Wahyudin (2015) dan Ghazali et al. (2015) yang menyatakan bahwa financial distress berpengaruh terhadap manajemen laba. Maka dari itu, financial distress mampu memediasi pengaruh good corporate governance terhadap manajemen laba.

Berdasarkan hasil pengujian menggunakan strategi causal step diperoleh hasil bahwa kinerja keuangan mampu mempengaruhi secara langsung manajenen laba tanpa melibatkan variabel mediasi financial distress. Hal ini dikarenakan variabel financial distress menjadi faktor penentu apabila perusahaan mengalami permasalahan keuangan, jika nilai financial distress terlalu rendah tentunya akan berdampak terhadap tingginya manajemen laba. Hal ini diperkuat dengan penelitian Suhadi \& Kusumaningtias (2018) dan Rohmadini et al. 2018) yang menyatakan bahwa kinerja keuangan tidak berpengaruh terhadap financial distress. Serta hasil penelitian Riadiani \& Wahyudin (2015) dan Ghazali et al. (2015) yang menyatakan bahwa financial distress berpengaruh terhadap manajemen laba dikarenakan kinerja keuangan tidak berpengaruh terhadap financial distress, maka financial distress tidak dapat memediasi pengaruh kinerja keuangan terhadap manajemen laba.

\section{SIMPULAN}

Hasil penelitian menunjukkan bahwa good corporate governance tidak berpengaruh terhadap manajemen laba, tetapi tidak dengan kinerja keuangan dan financial distress yang berpengaruh negatif dan signifikan terhadap manajemen laba. Kinerja keuangan tidak berpengaruh terhadap financial distress, tetapi tidak dengan good corporate governance yang berpengaruh negatif dan signifikan terhadap financial distress. Financial distress memediasi pengaruh good corporate governance terhadap manajemen laba, dan financial distress tidak memediasi pengaruh kinerja keuangan terhadap manajemen laba.

Bank Umum Syariah sebaiknya tidak melakukan tindakan manajemen laba karena dapat mengakibatkan informasi laporan keuangan tidak relevan dan akurat sehingga tidak menggambarkan kondisi keuangan yang sebenarnya. Bank Syariah juga harus memperkuat fungsi pengawasan agar terhindar dari praktik manajemen laba yang dilakukan tidak berdasarkan ketentuan karena fungsi pengawasan yang baik akan mengurangi tidak kecurangan.

\section{PUSTAKA ACUAN}

Abdillah, S. Y., Susilawati, R. A. E., \& Purwanto, N. (2014). Pengaruh Good Corporate Governance Pada Manajemen Laba (Studi Empiris Pada Perusahaan Manufaktur Yang Terdaftar Di Bursa Efek Indonesia Tahun 2013-2014). Journal Riset Mahasiswa Akuntansi (JRMA), $4(1), 1-14$.

Anhara. (2015). Analisis Faktor-Faktor Yang Mempengaruhi Manajemen Laba (Studi Pada Perusahaan Perbankan Syariahdi Indonesia). Jurnal TEKUN, 6(1), 128-150.

Belkaoui, A. R. (1993). Accounting Theory. Cambridge: The University Press.

Chhapra, I. U., Zehra, I., Kashif, M., \& Rehan, R. (2020). Is Bankruptcy Risk a Systematic Risk? Evidence from Pakistan Stock Exchange. Etikonomi, 19(1), 51-62. 
Damayanti, C. D., \& Kawedar, W. (2019). Pengaruh Profitabilitas, Mekanisme Pemantauan Dan Financial Distress Terhadap Manajemen Laba. Diponegoro Journal of Accounting, 7(4), 1-9.

Demirkan, S., \& Platt, H. (2009). Financial Status, Corporate Governance Quality, and The Likelihood of Managers Using Discretionary Accruals. Accounting Research Journal, 22(2), 93-117. https://doi.org/10.1108/10309610910987475.

Dewi, I. G. A. R., Rahindayati, N. M., \& Permanasukma, M. L. (2019). Pengaruh Faktor Internal Perusahaan Terhadap Manajemen Laba. Jurnal Sains, Akuntansi dan Manajemen (JSAM), 1(4), 550-575. https://doi.org/10.1234/jsam.v4i1.76.

Ewanto, M., Haryeti., \& Fathoni, A. F. (2011). Pengaruh Mekanisme Good Corporate Governance, Financial Distress Terhadap Earning Management Dengan Variabel Financial Distress Sebagai Mediasi: Studi Empiris Pada Perusahaan Pertambangan Yang Terdaftar Di Bursa Efek Indonesia. Jurnal Online Mahasiswa Fakultas Ekonomi, 1(1), 26-35.

Ghazali, A. W., Shafie, N. A., \& Sanusi, Z. M. (2015). Earnings Management: An Analysis of Opportunistic Behaviour, Monitoring Mechanism and Financial Distress. Procedia Economics and Finance, 28, 190-201. http://doi.org/10.1016/S2212-5671(15)01100-4.

Gunawijaya, I. N. A. (2015). Pengaruh Karakteristik Komite Audit, Independensi Dewan Komisaris, Reputasi Auditor Terhadap Financial Distress. Jurnal Akuntansi Bisnis, 14(27), 32-40.

Haq, H. I., \& Harto, P. (2019). Pengaruh Tingkat Kesehatan Bank Berbasis RGEC Terhadap Financial Distress (Studi Pada Perusahaan Perbankan Yang Terdaftar Di BEI Tahun 2015-2017). Diponegoro Journal of Accounting, 8(3), 1-12.

Haziroh, A. L., \& Negoro, N. (2017). Pengaruh Karakteristik Komite Audit Terhadap Financial Distress Perbankan Indonesia. Jurnal Sains dan Seni ITS, 6(1), 32-36.

Janrosl, V. S. E, \& Lim, J. (2019). Analisis Pengaruh Good Corporate Governance Terhadap Manajemen Laba Pada Perusahaan Perbankan Yang Terdaftar Di BEI. Owner: Riset dan Jurnal Akuntansi, 3(2), 226-238.

Juliansyah, N. (2011). Metodologi Penelitian: Skripsi, Tesis, Disertasi, Dan Karya Ilmiah. Jakarta: Penerbit Kencana.

Masak, F., \& Noviyanti, S. (2019). Pengaruh Karakteristik Komite Audit Terhadap Financial Distress. International Journal of Social Science and Business, 3(3), 237-245.

Muhammad. (2008). Metodologi Penelitian Ekonomi Islam: Pendekatan Kuantitatif. Jakarta: PT. Raja Grafindo Persada.

Putri, F. A., \& Machdar, N. M. (2017). Pengaruh Asimetri Informasi Arus Kas Bebas Dan Ukuran Perusahaan Terhadap Manajemen Laba. Kalbis Socio: Jurnal Bisnis dan Komunikasi, 4(1), 83-92.

Riadiani, A. R., \& Wahyudin, A. (2015). Pengaruh Good Corporate Governance Terhadap Manajemen Laba Dengan Financial Distress Sebagai Intervening. Accounting Analysis Journal, 4(3), 1-9. https://doi.org/10.15294/aaj.v4i3.8307.

Rohmadini, A., Saifi, M., \& Darmawan, A. (2018). Pengaruh Profitabilitas, Likuiditas Dan Leverage Terhadap Financial Distress (Studi Pada Perusahaan Food \& Beverage Yang Terdaftar Di Bursa Efek Indonesia Periode 2013-2016). Jurnal Administrasi Bisnis, 61(2), 11-19. 
Saraswati, R., Sulistyo., \& Mustikowati, R. (2016). Pengaruh Good Corporate Governance Dan Financial Distress Terhadap Manajemen Laba (Studi Kasus Pada Perbankan Yang Listing Di Bursa Efek Indonesia Periode 2011-2014). Jurnal Riset Mahasiswa Akuntansi Unikama, 4(1), 71-80.

Shidiq, I., \& Wibowo, B. (2017). Prediksi Financial Distress Bank Umum di Indonesia: Analisis Diskriminan dan Regresi Logistik. Esensi: Jurnal Bisnis dan Manajemen, 7(1), 27-40.

Suhadi, A., \& Kusumaningtias, R. (2018). Pengaruh Rasio Keuangan Terhadap Kondisi Financial Distress Bank Umum Syariah Di Indonesia. Jurnal Akuntansi AKUNESA 6(3), 1-25.

Sulistyoningsih, N., \& Asyik, N. F. (2019). Pengaruh Good Corporate Governance Dan Kinerja Keuangan Terhadap Manajemen Laba. Jurnal Ilmu dan Riset Akuntansi, 8(3): 1-20.

Suryanto, T. (2017). Manajemen Laba Pada Bank Syariah Di Indonesia: Peran Komite Audit dan Dewan Pengawas Syariah. Kinerja, 18(1): 90.

Vinet, L., \& Zhedanov, A. (2011). A 'missing' Family of Classical Orthogonal Polynomials. Journal of Physics A: Mathematical and Theoretical, 44(8), 1689-1699. 